\title{
Association between obesity and periodontal disease. A systematic review of epidemiological studies and controlled clinical trials
}

\author{
Mayte Martinez-Herrera ${ }^{1}$, Javier Silvestre-Rangil ${ }^{2}$, Francisco-Javier Silvestre ${ }^{3,4}$ \\ ${ }^{1}$ Dentist. Grant fellow (VALI+d) of the Regional Ministry Education of Valencian Community. Special Patients Unit, Depart- \\ ment of Stomatology, University of Valencia, Valencia, Spain \\ ${ }^{2}$ DDS, PhD. Associate Professor, Special Patients Unit, Department of Stomatology, University of Valencia, Valencia, Spain \\ ${ }^{3}$ DDS, PhD. Assistant Professor, Special Patients Unit, Department of Stomatology, University of Valencia, Valencia, Spain \\ ${ }^{4}$ MD. Service of Stomatology, University Hospital Doctor Peset, Av. Gaspar Aguilar 90, 46017 Valencia, Spain
}

Correspondence:

Clínica Odontológica Universitaria

Unidad de Odontología en Pacientes Especiales

Gascó Oliag 1, 46021 -Valencia, Spain

francisco.silvestre@uv.es
Martinez-Herrera M, Silvestre-Rangil J, Silvestre FJ. Association between obesity and periodontal disease. A systematic review of epidemiological studies and controlled clinical trials. Med Oral Patol Oral Cir Bucal. 2017 Nov 1;22 (6):e708-15.

http://www.medicinaoral.com/medoralfree01/v22i6/medoralv22i6p708.pdf

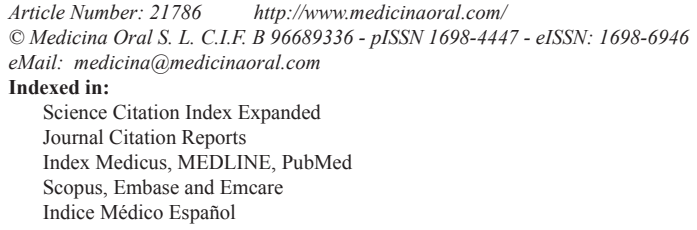

\begin{abstract}
Background: Obesity is a very prevalent chronic disease worldwide and has been suggested to increase susceptibility of periodontitis. The aim of this paper was to provide a systematic review of the association between obesity and periodontal disease, and to determine the possible mechanisms underlying in this relationship.

Material and Methods: A literature search was carried out in the databases PubMed-Medline and Embase. Controlled clinical trials and observational studies identifying periodontal and body composition parameters were selected. Each article was subjected to data extraction and quality assessment.

Results: A total of 284 articles were identified, of which 64 were preselected and 28 were finally included in the review. All the studies described an association between obesity and periodontal disease, except two articles that reported no such association. Obesity is characterized by a chronic subclinical inflammation that could exacerbate other chronic inflammatory disorders like as periodontitis.

Conclusions: The association between obesity and periodontitis was consistent with a compelling pattern of increased risk of periodontitis in overweight or obese individuals. Although the underlying pathophysiological mechanism remains unclear, it has been pointed out that the development of insulin resistance as a consequence of a chronic inflammatory state and oxidative stress could be implicated in the association between obesity and periodontitis. Further prospective longitudinal studies are needed to define the magnitude of this association and to elucidate the causal biological mechanisms.
\end{abstract}

Key words: Periodontal disease, periodontitis, periodontal infection, obesity, abdominal obesity.

\section{Introduction}

Obesity has been described as one of the most neglected public health problems, affecting both developed and developing countries (1). The prevalence of obesity has increased substantially in the last few decades $(2,3)$. In
2014, the World Health Organization (WHO) estimated that around 600 million obese adults worldwide were obese (4), and a further increase is expected in the future due to increased consumption of high-calorie diets and a sedentary lifestyle. 
Obesity is usually defined as body mass index (BMI = $\mathrm{kg} / \mathrm{m}^{2}$ ). Specifically, overweight is defined as a BMI between $25.0-29.9 \mathrm{~kg} / \mathrm{m}^{2}$ and obesity is defined as a BMI of $\geq 30.0 \mathrm{~kg} / \mathrm{m}^{2}(1-3)$. The exception is found in Asian regions, where overweight is defined as BMI $\geq 23 \mathrm{~kg}$ / $\mathrm{m} 2$, since in this setting obesity-related complications have been observed at comparatively lower BMI values (4). BMI is an indicator of total adiposity, but does not assess body mass distribution, so other parameters such as waist circumference (WC) or waist/hip ratio (WHR) are usually used (4). WC $\geq 102 \mathrm{~cm}$ in males and $\geq 88$ $\mathrm{cm}$ in females, and WHR $>0.90$ in males and $>0.85$ in females indicate abdominal obesity associated to an increased risk of morbidity (1-3). These anthropometric determinations show a close correlation to the amount of visceral adipose tissue, which has been shown to be metabolically more active and secretes larger amounts of cytokines and hormones compared to subcutaneous adipose tissue (1-3).

Obesity is a chronic metabolic disease that predisposes to a variety of comorbidities including arterial hypertension, type 2 diabetes mellitus, atherosclerosis and cardiovascular diseases (3). Furthermore, obesity has been suggested to be a risk factor for periodontitis (1-3).

Periodontal disease is an infectious and inflammatory disorder of tooth-supporting structures resulting from the interaction between pathogenic bacteria and the host immune response (1). Activation of the host immune system, primarily for protective purposes, eventually leads to destruction of tissues through the synthesis and release of cytokines, proinflammatory mediators and metalloproteinases (5).

Periodontitis is among the 10 most prevalent chronic diseases affecting the world's population (6). In recent years, research has focused on the relationship between periodontitis and systemic disorders such as diabetes mellitus, rheumatoid arthritis, cardiovascular diseases and obesity. The association between obesity and periodontitis is one of the most recent fields of research in periodontal medicine and the possible underlying biological mechanisms remain unclear. However, adipose tissue releases proinflammatory cytokines and hormones globally referred to as adipocytokines, which induce inflammatory processes and oxidative stress disorders, generating a similar pathophysiology between the both diseases $(2,3)$.

This association was first reported in animals in 1977 by Perlstein and Bissada, and in humans in 1998 by Saito et al. Since then, the hypothesis that obesity is a risk factor for periodontitis has been evidenced by several epidemiological studies (7-29).

Therefore, the aim of the present study was to offer a systematic review of the evidence on the association between obesity and periodontal disease, and of the possible mechanisms involved in this relationship. The following questions were raised in this regard: Do obese subjects have more periodontal disease? Is periodontal disease more aggressive in such population? What biological mechanisms are involved in the association between obesity and periodontal disease?

\section{Material and Methods}

In the present study the PubMed and Embase databases were used for the collection of articles. We performed a first exploratory search through PubMed in the Medline database, using the following key words in different combinations: periodontal diseases OR periodontitis OR periodontal infection AND obesity OR abdominal obesity. The filters used in this first search were publications in English and studies conducted in humans: "Periodontal diseases"[Majr] AND "Obesity"[MeSH] AND ("humans"[MeSH Terms] AND English[lang]). Based on these keywords we obtained a total of 192 references, and the corresponding titles and abstracts were then read to compile the publications of interest.

The inclusion criteria were: controlled clinical trials, cohort and case-control studies assessing obesity and periodontal disease, studies in adults (over 18 years of age), articles published in English and after the year 2000.

Clinical cases and case series, non-human studies, studies in individuals less than 18 years of age and published in languages other than English were excluded. Furthermore, we excluded studies on metabolic syndrome and those in which the periodontal status was only assessed by tooth loss, oral hygiene, gingival appearance or use of dental prostheses. Studies that did not exclude diabetic patients or individuals with systemic inflammatory disorders, or which made no adjustment for such confounding factors, were also excluded.

A complementary search was subsequently performed in the Embase database, entering the same keywords and considering the same inclusion and exclusion criteria ('periodontal diseases' AND obesity AND [English]/ $\lim$ AND [humans]/lim). From the articles obtained we discarded those that had already been identified in the first search in PubMed; and we obtained 2 articles that were exclusively found in Embase.

\section{Results - Discussion}

The flowchart corresponding to the search process is shown in Figure 1. The search identified a total of 248 articles, of which 64 were preselected on the basis of the inclusion and exclusion criteria, and 28 were finally included in the review: 19 observational studies (7-14,1618,20-22,24,26-29) described in Table 1, and 9 clinical trials of periodontal treatment (30-38) reported in Table 2 . Studies are listed chronologically from the most recent article, based on the publication date (and then in alphabetical order within that same year). 


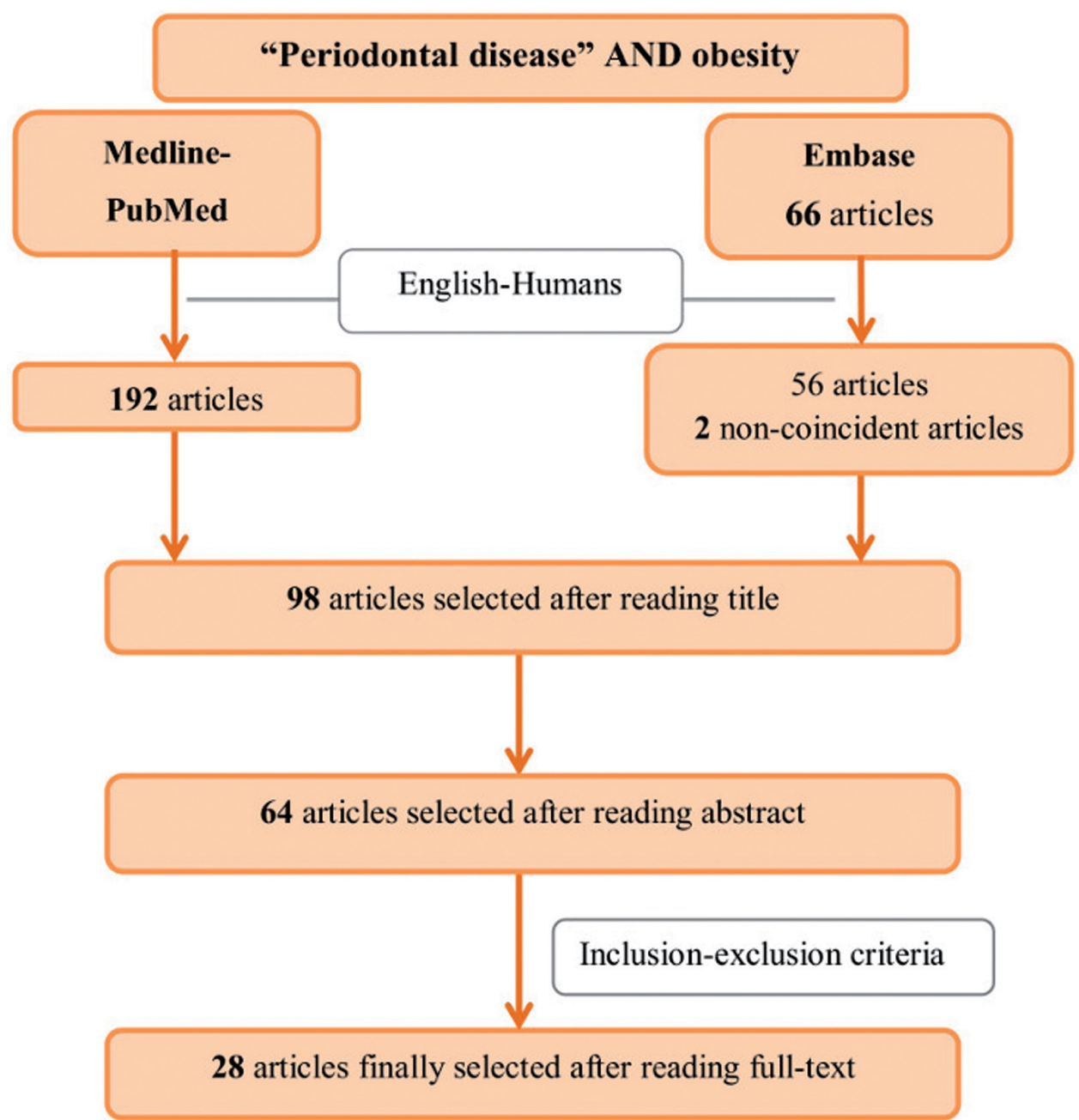

Fig. 1. Flowchart of the search process.

An association between periodontal disease and obesity has been demonstrated in the worldwide literature. Most of the 19 observational studies were of a crosssectional nature, with very few prospective longitudinal studies $(8-10,13,16,22)$. The results of some crosssectional studies show that obese individuals have more periodontal disease than the normal weight population, and some publications have found this association to be stronger as the obesity level increases (11). Some of the reviewed prospective studies $(8,9,13,22)$ suggest that overweight, obesity, weight gain and a large WC may be risk factors for the development or worsening of periodontitis. Three prospective studies $(9,10,13)$ found a direct association between obesity and the subsequent development of periodontitis. In turn, two of these studies $(10,13)$ also determined a direct association between overweight and the development of periodontitis.

Although most studies evidence an association between obesity and periodontal disease, of the 19 observational studies, two $(16,17)$ described no significant association between obesity and periodontitis. Furthermore, one of them reported an inverse relationship between obesity and periodontal clinical attachment loss (17). However, these results lack a solid basis, since these studies use multiple variables using different cut-off points for evaluate obesity and periodontal disease.

Most of studies that reported an association between obesity and periodontitis focused on disease prevalence, and three informed of the extent and severity of periodontal disease $(14,21,28)$.

In general, all the studies evaluated anthropometric and periodontal parameters to determine the association between the two disorders. All of them evaluated the degree of obesity by calculating BMI, and some of them also included other measures of abdominal obesity such as WC, WHR and, in some cases, even percentage body 
Table 1. Epidemiological studies on the association between obesity and periodontal disease.

\begin{tabular}{|c|c|c|c|c|c|c|c|c|c|}
\hline Article & Study design & Country & $\mathbf{n}$ & Sex & $\begin{array}{l}\text { Control } \\
\text { group }\end{array}$ & $\begin{array}{c}\text { Exclusion DM } \\
\text { and } \\
\text { inflammatory } \\
\text { diseases }\end{array}$ & $\begin{array}{l}\text { Definition } \\
\text { of obesity }\end{array}$ & $\begin{array}{l}\text { Definition of } \\
\text { Periodontitis }\end{array}$ & $\begin{array}{l}\text { Significant } \\
\text { association }\end{array}$ \\
\hline $\begin{array}{l}\text { Buduneli et al. } 2014 \\
\text { (7) }\end{array}$ & Case-control & Turkey & 91 & F & Yes & Yes & $\begin{array}{l}\text { BMI } \\
\text { WHR }\end{array}$ & $\begin{array}{l}\text { PD, CAL, PI, } \\
\text { BOP }\end{array}$ & $\begin{array}{l}\text { Yes (CAL, PI) } \\
\text { No (PD, BOP) }\end{array}$ \\
\hline Ekuni et al. 2014(8) & Cohort & Japan & 224 & $\mathrm{~F} / \mathrm{M}$ & Yes & Yes & BMI & $\begin{array}{l}\text { PCI, BOP, PD, } \\
\text { PI, CI }\end{array}$ & $\begin{array}{c}\text { Yes (BMI, PCI) } \\
\text { No (BMI, BOP } \\
\text { and PD) }\end{array}$ \\
\hline $\begin{array}{l}\text { Gorman et al. } 2012 \\
\text { (9) }\end{array}$ & Cohort & $\begin{array}{c}\text { United } \\
\text { Kingdom }\end{array}$ & 1038 & $\mathrm{M}$ & Yes & No (Adjust.) & $\begin{array}{l}\text { BMI, WC } \\
\text { WHR }\end{array}$ & ABL, PD, CAL & $\begin{array}{c}\text { Yes (obesity, } \\
\text { WC) } \\
\text { No (OW) }\end{array}$ \\
\hline $\begin{array}{l}\text { Jimenez et al. } 2012 \\
\text { (10) }\end{array}$ & Cohort & $\begin{array}{c}\text { United } \\
\text { Kingdom }\end{array}$ & $\begin{array}{c}3691 \\
0\end{array}$ & $\mathrm{M}$ & Yes & No (Adjust.) & $\begin{array}{l}\text { BMI, WC } \\
\text { WHR } \\
\text { (Self- } \\
\text { reported) }\end{array}$ & $\begin{array}{l}\text { Self-reported } \\
\text { (Yes/No) }\end{array}$ & $\begin{array}{c}\text { Yes (OW, } \\
\text { obesity, WC) }\end{array}$ \\
\hline $\begin{array}{l}\text { Luiz Pataro et al. } \\
2012(11)\end{array}$ & Case-control & Brazil & 594 & $\mathrm{~F}$ & Yes & No (Adjust.) & BMI & $\begin{array}{c}\text { BOP, } \\
\text { suppuration, } \\
\text { PD, CAL, PI, } \\
\text { Periodontitis }\end{array}$ & $\begin{array}{l}\text { Yes (obesity } \\
\text { and OW) }\end{array}$ \\
\hline Kim et al. 2011(12) & Case-control & Korea & 4246 & $\mathrm{~F} / \mathrm{M}$ & Yes & No (Adjust.) & $\begin{array}{l}\text { BMI } \\
\text { WC }\end{array}$ & $\mathrm{PCI}$ & $\begin{array}{l}\text { Yes (WC) } \\
\text { No (BMI) }\end{array}$ \\
\hline Morita et al. 2011(13) & Cohort & Japan & 3590 & $\mathrm{~F} / \mathrm{M}$ & Yes & No (Adjust.) & BMI & $\begin{array}{c}\text { PD, } \\
\text { Periodontitis }\end{array}$ & $\begin{array}{c}\text { Yes (OW, } \\
\text { obesity in F) } \\
\text { No (obesity in } \\
\text { M) }\end{array}$ \\
\hline Saxlin et al. 2011(14) & Case-control & Finland & 2784 & $\mathrm{~F} / \mathrm{M}$ & Yes & Yes & $\begin{array}{c}\text { BMI, WC } \\
\% \text { fat }\end{array}$ & $\begin{array}{l}\text { PD } \\
\text { PI }\end{array}$ & $\begin{array}{l}\text { Yes (BMI, \% } \\
\text { fat and WC) }\end{array}$ \\
\hline Saxlin et al. $2010(16)$ & Cohort & Finland & 396 & F/M & Yes & Yes & BMI & $\begin{array}{l}\text { Periodontitis } \\
\text { (PD) }\end{array}$ & $\begin{array}{l}\text { No (OW, } \\
\text { obesity) }\end{array}$ \\
\hline $\begin{array}{l}\text { Kongstad et al. } 2009 \\
\text { (17) }\end{array}$ & Case-control & Denmark & 1504 & $\mathrm{~F} / \mathrm{M}$ & Yes & No (Adjust.) & BMI & $\begin{array}{l}\text { CAL, BOP, PD, } \\
\text { PI }\end{array}$ & No \\
\hline Saxlin et al. $2009(18)$ & Cohort & Finland & 425 & $\mathrm{~F} / \mathrm{M}$ & No & Yes & BMI & PD, CAL, PI & Yes \\
\hline Saxlin et al. $2008(20)$ & Case-control & Finland & 1297 & $\mathrm{~F} / \mathrm{M}$ & Yes & Yes & BMI & PD, PI & Yes \\
\hline $\begin{array}{l}\text { Ylöstalo et al. } 2008 \\
\text { (21) }\end{array}$ & Case-control & Finland & 2841 & $\mathrm{~F} / \mathrm{M}$ & Yes & Yes & $\begin{array}{c}\text { BMI, WC } \\
\% \text { fat }\end{array}$ & PD, PI & Yes \\
\hline $\begin{array}{l}\text { Linden et al. } 2007 \\
\text { (22) }\end{array}$ & Cohort & Ireland & 1362 & $\mathrm{M}$ & Yes & No (Adjust.) & BMI & $\begin{array}{l}\text { PD, CAL, } \\
\text { Periodontitis }\end{array}$ & Yes (obesity) \\
\hline Genco et al. 2005 (24) & Case-control & EEUU & $\begin{array}{c}1236 \\
7\end{array}$ & F/M & Yes & Yes & BMI & $\begin{array}{l}\text { PD, CAL, BOP, } \\
\text { CI, Periodontitis }\end{array}$ & Yes \\
\hline Saito et al. $2005(26)$ & Cohort & Japan & 584 & $\mathrm{~F}$ & Yes & No (Adjust.) & $\begin{array}{c}\text { BMI, WC } \\
\text { WHR, } \\
\% \text { fat }\end{array}$ & PD, CAL, PI & Yes \\
\hline $\begin{array}{l}\text { Al-Zahrani et al. } 2003 \\
\text { (27) }\end{array}$ & Case-control & EEUU & $\begin{array}{c}1366 \\
5\end{array}$ & $\mathrm{~F} / \mathrm{M}$ & Yes & No (Adjust.) & $\begin{array}{l}\text { BMI } \\
\text { WC }\end{array}$ & $\begin{array}{l}\text { PD, CAL, } \\
\text { Periodontitis }\end{array}$ & Yes \\
\hline Wood et al. 2003 (28) & Case-control & EEUU & $\begin{array}{c}1766 \\
0\end{array}$ & $\mathrm{~F} / \mathrm{M}$ & Yes & No (Adjust.) & $\begin{array}{c}\text { BMI, WC } \\
\text { WHR, FFM }\end{array}$ & $\begin{array}{c}\text { CAL, PD, BOP, } \\
\text { CI }\end{array}$ & Yes \\
\hline Saito et al. 2001 (29) & Case-control & Japan & 643 & $\mathrm{~F} / \mathrm{M}$ & Yes & No (Adjust.) & $\begin{array}{c}\text { BMI, WHR } \\
\% \text { fat }\end{array}$ & PD & Yes \\
\hline
\end{tabular}

F: females, M: males, DM: diabetes mellitus, BMI: body mass index, WHR: waist/hip ratio, WC: waist circumference, PD: probing depth, CAL: clinical attachment loss, PI: plaque index, BOP: bleeding of probing, PCI: Periodontal Community Index, OW: overweight, ABL: alveolar bone loss, FFM: free fat mass.

fat $(14,21,26,28,29)$. A stronger correlation has been observed between periodontitis and anthropometric measures of visceral fat accumulation than between periodontitis and BMI. In fact, one of the studies reported a significant relationship between periodontal disease and WC, without correlation to BMI (12). This is consistent with the fact that abdominal adipose tissue secretes a diversity of adipocytokines, which induce inflammatory processes and oxidative stress disorders, resulting in a chronic activation of the acute phase response and the development of insulin resistance (IR).

In the same way, some studies identified a direct asso- 
Table 2. Studies of periodontal treatment in subjects with obesity and normal weight.

\begin{tabular}{|c|c|c|c|c|c|c|c|c|c|c|}
\hline Article & $\begin{array}{l}\text { Study } \\
\text { design }\end{array}$ & Country & $\mathrm{n}$ & Sex & $\begin{array}{c}\text { Exclusion } \\
\text { DM and } \\
\text { inflammatory } \\
\text { diseases }\end{array}$ & $\begin{array}{l}\text { Follow- } \\
\text { up }\end{array}$ & $\begin{array}{l}\text { Definition of } \\
\text { Periodontitis }\end{array}$ & $\begin{array}{c}\text { Periodontal } \\
\text { treatment }\end{array}$ & Exposure & $\begin{array}{c}\text { Impact } \\
\text { obesity on } \\
\text { periodontal } \\
\text { treatment } \\
\text { response } \\
\end{array}$ \\
\hline $\begin{array}{l}\text { Balli et al. } 2016 \\
(30)\end{array}$ & Clinical trial & Turkey & 80 & $\mathrm{M} / \mathrm{F}$ & Yes & 6 weeks & $\begin{array}{l}\text { Periodontitis } \\
\text { (PD, CAL, } \\
\text { GI, BOP, PI) }\end{array}$ & $\begin{array}{l}\text { Non- } \\
\text { surgical } \\
\text { SRP }\end{array}$ & $\begin{array}{l}\text { Obese-CP } \\
\text { vs. NW- } \\
\text { CP. }\end{array}$ & No \\
\hline $\begin{array}{l}\text { Duzagac et al. } \\
2016(31)\end{array}$ & Clinical trial & Turkey & 45 & $\mathrm{M} / \mathrm{F}$ & Yes & $\begin{array}{c}3 \\
\text { months }\end{array}$ & $\begin{array}{c}\text { Periodontitis } \\
\text { (PD, CAL, PI, } \\
\text { GI, BOP) }\end{array}$ & $\begin{array}{l}\text { Non- } \\
\text { surgical } \\
\text { SRP }\end{array}$ & $\begin{array}{l}\text { Obese-CP } \\
\text { vs. Non- } \\
\text { obese-CP } \\
\text { vs. Non- } \\
\text { CP }\end{array}$ & $\begin{array}{c}\text { No. } \\
\text { Negative in } \\
\text { serum CRP } \\
\text { and } \\
\text { adipocytoki } \\
\text { nes levels }\end{array}$ \\
\hline $\begin{array}{l}\text { Bouaziz et al. } \\
2015(32)\end{array}$ & Clinical trial & France & 36 & $\mathrm{M} / \mathrm{F}$ & Yes & $\begin{array}{l}3 \text { and } 6 \\
\text { months }\end{array}$ & $\begin{array}{c}\text { Periodontitis } \\
\text { (PD, CAL, PI, } \\
\text { BOP) }\end{array}$ & $\begin{array}{l}\text { Non- } \\
\text { surgical } \\
\text { SRP }\end{array}$ & $\begin{array}{l}\text { Obese-CP } \\
\text { vs. NW- } \\
\text { CP }\end{array}$ & Yes \\
\hline $\begin{array}{l}\text { Dias Gonçalves et } \\
\text { al. 2015(33) }\end{array}$ & Clinical trial & Brazil & 48 & $\mathrm{M} / \mathrm{F}$ & Yes & $\begin{array}{l}3 \text { and } 6 \\
\text { months }\end{array}$ & $\begin{array}{l}\text { Periodontitis } \\
\text { (PI, BOP, } \\
\text { suppuration, } \\
\text { PD, CAL) }\end{array}$ & $\begin{array}{l}\text { Non- } \\
\text { surgical } \\
\text { SRP }\end{array}$ & $\begin{array}{l}\text { Obese-CP } \\
\text { vs. Non- } \\
\text { obese-CP }\end{array}$ & Yes \\
\hline $\begin{array}{l}\text { Öngöz Dede } \text { et al. } \\
2015(34)\end{array}$ & Clinical trial & Turkey & 90 & $\mathrm{M} / \mathrm{F}$ & Yes & 1 month & $\begin{array}{l}\text { Periodontitis } \\
\text { (PD, CAL, } \\
\text { GI, BOP, PI) }\end{array}$ & $\begin{array}{l}\text { Non- } \\
\text { surgical } \\
\text { SRP }\end{array}$ & $\begin{array}{c}\text { Obese-G } \\
\text { and } \\
\text { Obese-CP } \\
\text { vs. NW-G } \\
\text { and NW- } \\
\text { CP }\end{array}$ & No \\
\hline $\begin{array}{l}\text { Suvan } \text { et al. } 2014 \\
(35)\end{array}$ & $\begin{array}{c}\text { Second } \\
\text { analysis } \\
\text { (data of } 5 \\
\text { clinical } \\
\text { trials) }\end{array}$ & $\begin{array}{l}\text { United } \\
\text { KingdomI } \\
\text { taly }\end{array}$ & 260 & $\mathrm{M} / \mathrm{F}$ & Yes & $\begin{array}{c}2 \\
\text { months }\end{array}$ & $\begin{array}{c}\text { Periodontitis } \\
\text { (PD, \%PD }>4 \\
\text { mm, CAL } \\
\text { BOP) }\end{array}$ & $\begin{array}{l}\text { Non- } \\
\text { surgical } \\
\text { SRP }\end{array}$ & $\begin{array}{c}\text { OW and } \\
\text { obese vs. } \\
\text { NW }\end{array}$ & Yes \\
\hline $\begin{array}{l}\text { Altay et al. } 2013 \\
\text { (36) }\end{array}$ & Clinical trial & Turkey & 46 & $\mathrm{M} / \mathrm{F}$ & Yes & $\begin{array}{c}3 \\
\text { months }\end{array}$ & $\begin{array}{c}\text { Periodontitis } \\
\text { (CAL, PD, PI, } \\
\text { GI, BOP) }\end{array}$ & $\begin{array}{l}\text { Non- } \\
\text { surgical } \\
\text { SRP }\end{array}$ & $\begin{array}{c}\text { Obese-CP } \\
\text { vs. } \\
\text { Non- } \\
\text { obese-CP }\end{array}$ & No \\
\hline $\begin{array}{l}\text { Al-Zahrani \& } \\
\text { AlGhamdi } 2012 \\
\text { (37) }\end{array}$ & Clinical trial & $\begin{array}{l}\text { Saudi } \\
\text { Arabia }\end{array}$ & 40 & $\mathrm{~F}$ & Yes & $\begin{array}{c}2 \\
\text { months }\end{array}$ & $\begin{array}{l}\text { Periodontitis } \\
\text { (CAL, PD, PI, } \\
\text { BOP) }\end{array}$ & $\begin{array}{l}\text { Non- } \\
\text { surgical } \\
\text { SRP }\end{array}$ & $\begin{array}{c}\text { Obese-CP } \\
\text { vs. } \\
\text { Non- } \\
\text { obese-CP }\end{array}$ & No \\
\hline $\begin{array}{l}\text { Zuza et al. } 2011 \\
(38)\end{array}$ & Clinical trial & Brazil & 52 & $\mathrm{M} / \mathrm{F}$ & Yes & $\begin{array}{c}3 \\
\text { months }\end{array}$ & $\begin{array}{l}\text { Periodontitis } \\
\text { (PD, CAL, } \\
\text { GI, PI, BOP) }\end{array}$ & $\begin{array}{l}\text { Non- } \\
\text { surgical } \\
\text { SRP }\end{array}$ & $\begin{array}{c}\text { Obese-CP } \\
\text { vs. } \\
\text { Non- } \\
\text { obese-CP }\end{array}$ & No \\
\hline
\end{tabular}

M: males, F: females, PD: probing depth, CAL: clinical attachment level, GI: gingival index, BOP: bleeding on probing, PI: plaque index; SRP: scaling and root planning, O: obese, OW: overweight, CP: chronic periodontitis, NW: normal weight, PCR: C-reactive protein, G: gingivitis.

ciation between periodontitis and overweight $(10,11,13)$, whereas in the study by Gorman et al. was established a correlation between periodontal disease and obesity but not overweight (9). Two longitudinal cohort studies $(8,9)$ determined that weight gain was directly associated to the development of periodontitis. In contrast, the study by Linden et al. found no association between weight gain from 21 to 60-70 years of age and the severity of periodontitis, determining that a high BMI at an early age is not predictive of periodontitis in old age (22).

The evaluation of periodontal disease was seen to vary greatly in the research setting. Some studies evaluated and compared periodontal parameters such as probing depth (PD), clinical attachment level (CAL), bleeding on probing (BOP), gingival index (GI), or plaque index (PI) and calculus index $(\mathrm{CI})$. The larger studies $(8,12)$ used the community periodontal index (CPI) and restricted measurements to representative teeth or quadrants. In turn, some studies established a diagnosis of periodontitis and classified the population according to the presence or absence of periodontitis, determining prevalence. The greatest agreement among the different studies was referred to the definition of periodontal disease as $\mathrm{PD} \geq 4$ $\mathrm{mm}$ and $\mathrm{CAL} \geq 3 \mathrm{~mm}$, although different definitions and combinations were employed. The nine interventional studies used the different periodontal parameters (PD, CAL, BOP, PI, GI) to assess periodontal disease and the changes following periodontal treatment. 
Of the 28 articles reviewed, three included only males $(9,10,22)$, four included only females $(7,11,26,37)$, and the remainder included individuals of both sexes. Of the latter, three studies $(13,14,17)$ analyzed males and females separately, and another 10 articles adjusted the analysis by gender $(8,12,16,18,20,21,24,27-29)$. Some studies $(15,24)$ indicate that males are at a greater risk of developing periodontitis than females, while other articles $(13,39)$ suggest that females may be more vulnerable to periodontitis, due to hormonal fluctuations that increase gingival inflammation. Nevertheless, Saxlin et al. $(14,16)$ suggest that gender does not appear to influence the association between obesity and periodontitis. Consequently, on the basis of the results of our review, it is not possible to draw firm conclusions regarding the influence of gender upon the association between obesity and the development of periodontitis.

Age has also been considered as a risk factor for periodontitis and has been observed that the prevalence and severity of periodontitis increase with age, probably as a consequence of the longer exposure of the periodontal tissues to bacterial plaque (39). However, since most of the included studies (8,9-14,16-18,20-22,24,26-29) adjusted the results according to age, the association between obesity and periodontitis seems to be independent of age. Regard to smoking habit, eleven studies $(8,16,18,20,30-34,37,38)$ excluded smokers, twelve adjusted the analysis for smoking as a confounding factor $(9-13,22,24,26-29,35)$, and three studies divided the study population into smokers and non-smokers $(7,14,17)$. In one of the latter, non-smoking obese women had a greater clinical attachment loss and greater bleeding and plaque index than non-obese and non-smoking women (7). Likewise, another two studies reported an association between the number of teeth with pathological periodontal pocket depths greater than or equal to 4 $\mathrm{mm}$ and BMI in a non-smoking subpopulation $(14,21)$. Therefore, although smoking habit predisposes to periodontitis and contributes to periodontal tissue destruction (39), it has been observed that smoking and obesity are independent risk indicators for periodontitis, and both conditions show a dose-dependent correlation to the risk of periodontitis (25).

This review has focused on studies that only examine the association between obesity and periodontitis, without considering other systemic diseases or oral disorders. As well as, we considered whether the study included a control group for comparison versus the obese individuals in order to establish a genuine association between obesity and periodontal disease. In this way, we considered whether the studies controlled for confounding factors by excluding those subjects with diabetes mellitus or other concomitant inflammatory conditions capable of influencing the results. Of the 28 articles reviewed, 17 excluded diabetic patients $(7,8,14,16,18,20,21,24,30$ -
38 ) and 11 controlled for diabetes as a confounding factor $(9-13,17,22,26-29)$. Nevertheless, it must be taken into account that despite the control of this confounding factor, those studies that did not exclude diabetic individuals were susceptible to possible bias in the interpretation of the results obtained.

Of the nine studies evaluating the effect of obesity upon the clinical and biochemical response to periodontal treatment, six $(30,31,34,36-38)$ concluded that obesity does not exert a negative modifying effect upon the outcome of non-surgical periodontal treatment. In contrast, three articles $(32,33,35)$ suggested that obesity exerts a negative effect upon periodontal treatment response. Therefore, to date, the effect of obesity on the response to periodontal treatment remains uncertain.

Some of the reviewed studies analyzed proinflammatory molecules in serum, in an attempt to identify a possible causal mechanism relating obesity to periodontitis. Most of the studies pointed to the inflammatory process as the possible cause. In obesity, adipocytes secrete proinflammatory cytokines such as TNF- $\alpha$ and IL-6, which stimulate the hepatic production of acute phase reactants such as C-reactive protein (CRP) and cause alterations in the host's immune response - increasing the susceptibility to bacterial infection (6). Likewise, TNF- $\alpha$ is one of the first proinflammatory cytokines induced by the pathogens of periodontitis. TNF- $\alpha$ contributes to the onset of periodontitis through the stimulation of osteoclast formation, inducing alveolar bone destruction and connective tissue degradation (40). It is therefore believed that TNF- $\alpha$ mainly contributes to the early stages in the development of periodontal disease in obese individuals, not to the worsening and/or progression of already established periodontitis. It has been reported that the serum TNF- $\alpha$ levels were not correlated to the severity of destructive periodontal disease in patients with BMI $>30 \mathrm{~kg} / \mathrm{m}^{2}$ (24).

Respect to IL-6, although in one study higher serum interleukin-6 (IL-6) levels were reported in obese individuals (7) and Saxlin et al. (18) found the serum IL-6 levels to be associated to periodontal infection, the association between IL-6 and periodontitis remains unclear, due to its dual pro- and antiinflammatory effects (40).

Similarly, the role of other molecules in the association between obesity and periodontitis, such as leptin, adiponectin and resistin, remain to be clarified. Leptin plays a protective role in immune system function, and is present in larger amounts in minimally inflamed gingival tissue, decreasing its concentration at sites presenting deeper pocket depths (3). Serum adiponectin - which exerts antiinflammatory effects - tends to decrease, and resistin - which exerts inflammatory effects - tends to increase in individuals with periodontitis (19).

Likewise, it has been reported that obesity may be associated to periodontitis through the increased produc- 
tion of reactive oxygen species (ROS). Excessive ROS levels and a decrease in antioxidant substances in the periodontal tissues result in a chronic activation of inflammation and tissue destruction (40). This chronic inflammation and oxidative stress could condition the development of IR. Recently, it has been suggested that IR plays a role in the pathogenesis of periodontitis (24). It has been seen that non-surgical periodontal treatment results in lowered serum TNF- $\alpha$ levels and decreased IR among the obese population (31,36).

Figure 2 shows a model of association between obesity and periodontal disease through inflammation and oxidative stress. However, the pathophysiological mechanism whereby obesity affects the periodontium remains unclear, and this association may be bidirectional $(3,40)$.
Most of the included studies involved a cross-sectional design, thereby precluding definition of the mechanisms underlying the association between both diseases. Further prospective studies are needed to confirm the causal relationship between obesity and periodontitis, as well as the pathophysiological mechanism involved in the association between both diseases.

\section{Conclusions}

The results of this study indicate the existence of an association between obesity and periodontitis and although the causal mechanisms underlying this association remain unclear, the development of insulin resistance as a consequence of a chronic inflammatory state and oxidative stress could be implicated in the association between obesity and periodontitis. This evidence

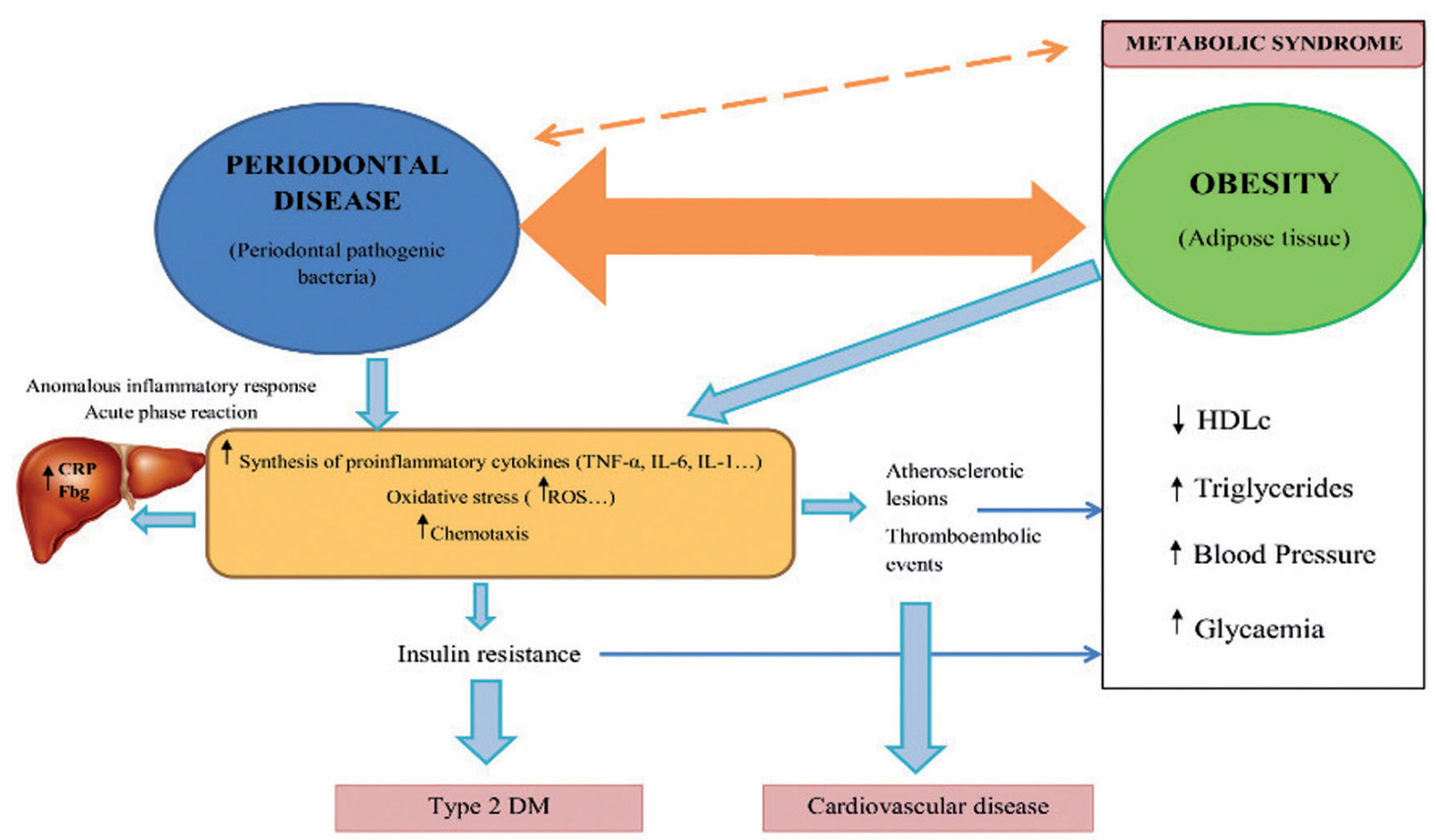

Fig. 2. Model of association between obesity and periodontal disease through inflammation, oxidative stress and insulin resistance. Abbreviations: CRP: C-reactive protein, Fbg: fibrinogen, TNF- $\alpha$ : tumor necrosis factor alpha, IL-6: inteleukin 6, IL-1: interleukin 1, ROS: reactive oxygen species, DM: diabetes mellitus, HDLc: HDL cholesterol.

points to the need for further prospective clinical studies, designed to define the magnitude of this association and clarify the role of IR in the pathogenesis of periodontitis.

\section{References}

1. Dahiya P, Kamal R, Gupt R. Obesity, periodontal and general health: relationship and management. Indian J Endocr Metab. 2012;16:89-93.
2. Jagannathachary S, Kamaraj D. Obesity and periodontal disease. J Indian Soc Periodontol. 2010;14:96-100.

3. Pischon N, Heng N, Bernimoulin JP, Kleber BM, Willich SN, Pischon T. Obesity, inflammation, and periodontal disease. J Dent Res. 2007;86:400-9.

4. World Health Organization. Obesity and overweight. Available at: http://www.who.int/mediacentre/factsheets/fs311/en/. Accessed: 1503-2015, 2015.

5. Oppermann RV, Weidlich P, Musskopf ML. Periodontal disease and systemic complications. Braz Oral Res. 2012;26:39-47. 
6. Nascimiento GG, Leite FR, Correa MB, Horta BL, Peres MA, Demarco FF. Relationship between periodontal disease and obesity: the role of life-course events. Braz Dent J. 2014;25:87-9.

7. Buduneli N, Biyikoglu B, Ilgenli T, Buduneli E, Nalbantsoy A, Saraç F, et al. Is obesity a possible modifier of periodontal disease as a chronic inflammatory process? A case-control study. J Periodont Res. 2014;49:465-71.

8. Ekuni D, Mizutani S, Kojima A, Tomofuji T, Irie K, Azuma T, et al. Relationship between increases in BMI and changes in periodontal status: a prospective cohort study. J Clin Periodontol. 2014;41:772-8. 9. Gorman A, Kaye EK, Apovian C, Fung TT, Nunn M, Garcia RI. Overweight and obesity predict time to periodontal disease progression in men. J Clin Periodontol. 2012;39:107-14.

10. Jimenez M, Hu FB, Marino M, Li Y, Joshipura KJ. Prospective associations between measures of adiposity and periodontal disease. Obesity. 2012;20:1718-25.

11. Luiz-Pataro A, Oliveira-Costa F, Cavalca-Cortelli S, Corterlli JR, Nogueira-Guimaraes Abreu MH, et al. Association between severty of body mass index and periodontal condition in women. Clin Oral Invest. 2012;16:727-34.

12. Kim EJ, Jin BH, Bae KH. Periodontitis and obesity: a study of the Fourth Korean National Health an Nutrition Examination Survey. J Periodontol. 2011;82:533-42.

13. Morita I, Okamoto Y, Yoshii S, Nakagaki H, Mizuno K, Sheiham A, et al. Five-year incidence of periodontal disease is related to body mass index. J Dent Res. 2011;90:199-202.

14. Saxlin T, Ylöstalo P, Suominen-Taipale L, Männistö S, Knuuttila M. Association between periodontal infection and obesity: results of the Health 2000 Survey. J Clin Periodontol. 2011;38:236-42.

15. Han DH, Lim SY, Sun BC, Paek DM, Kim HD. Visceral fat areadefined obesity and periodontitis among Koreans. J Clin Periodontol. 2010;37:172-9.

16. Saxlin T, Ylöstalo P, Suominen-Taipale L, Aromaa A, Knuuttila M. Overweight and obesity weakly predict the development of periodontal infection. J Clin Periodontol. 2010;37:1059-67.

17. Kongstad J, Hvidtfeldt UA, Gronback M, Stoltze K, Holmstrup P. The relationship between body mass index and periodontitis in the Copenhagen city hearth study. J Periodontol. 2009;80:1246-53.

18. Saxlin T, Suominen-Taipale L, Leiviskä J, Jula A, Knuuttila M, Ylölstalo P. Role of serum cytokines tumour necrosis factor- $\alpha$ and IL-6 in the association between body weight and periodontal infection. J Clin Periodontol. 2009;36:100-5.

19. Saito T, Yamaguchi N, Shimazaki Y, Hayashidaa H, Yonemoto K, Doi Y, et al. Serum levels of resistin and adiponectin in women with periodontitis: the Hisayama study. J Dent Res. 2008;87:319-22. 20. Saxlin T, Suominen-Taipale L, Kattainen A, Marniemi J, Knuuttila M, Ylöstalo P. Association between serum lipid levels and periodontal infection. J Clin Periodontol. 2008;35:1040-7.

21. Ylöstalo P, Suominen-Taipale L, Reunanen A, Knuuttila M. Association between body weight and periodontal infection. J Clin Periodontol. 2008;35:297-304.

22. Linden G, Patterson C, Evans A, Kee F. Obesity and periodontitis in 60-70-year-old men. J Clin Periodontol. 2007;34:461-6.

23. Dalla Vecchia CF, Susin C, Kuchenbecker C, Oppermann R, Albandar J. Overweight and obesity as risk indicators for periodontitis in adults. J Periodontol. 2005;76:1721-8.

24. Genco RJ, Grossi SG, Ho A, Nishimura F, Murayama Y. A proposed model linking inflammation to obesity, diabetes, and periodontal infections. J Periodontol. 2005;76:2075-84.

25. Nishida N, Tanaka M, Hayashi N, Nagata H, Takeshita T, Nakayama K, et al. Determination of smoking and obesity as periodontitis risks using the classification and regression tree method. $\mathrm{J}$ Periodontol. 2005;76:923-8.

26. Saito T, Shimazaki Y, Kiyohara Y, Kato I, Kubo M, Iida M, et al. Relationship between obesity, glucose tolerance, and periodontal disease in Japanese women: the Hisayama study. J Periodontal Res. 2005;40:346-53.

27. Al-Zahrani MS, Bissada NF, Borawski EA. Obesity and periodontal disease in young, middle-aged, and older adults. J Periodon- tol. $2003 ; 74: 610-5$.

28. Wood N, Johnson RB, Streckfus CF. Comparison of body composition and periodontal disease using nutritional assessment techniques: Third National Health and Nutrition Examination Survey (NHANES III). J Clin Periodontol. 2003;30:321-7.

29. Saito T, Shimazaki Y, Koga T, Tsuzuki M, Ohshima A. Relationship between upper body obesity and periodontitis. J Dent Res. 2001;80:1631-6.

30. Balli U, Öngöz Dede F, Bozkurt Dogan S, Gulsoy Z, Sertoglu E. Chemerin and interleukin-6 levels in obese individuals following periodontal treatment. Oral Dis. 2016; 22:673-80.

31. Duzagac E, Cifcibasi E, Erdem MG, Karabey V, Kasali K, Badur $\mathrm{S}$, et al. Is obesity associated with healing after non-surgical periodontal therapy? A local vs. systemic evaluation. J Periodont Res. 2016; 51:604-12

32. Bouaziz W, Davideau JL, Tenenbaum H, Huck O. Adiposity Measurements and Non-Surgical Periodontal Therapy Outcomes. J Periodontol. 2015; 86:1030-1037.

33. Dias Gonçalves TE, Feres M, Santos Zimmermann G, Faveri M, Figueiredo LC, Gralha Braga P, et al. Effects of Scaling and Root Planing on Clinical Response and Serum Levels of Adipocytokines in Patients With Obesity and Chronic Periodontitis. J Periodontol. 2015; 86:53-61.

34. Öngöz Dede F, Bozkurt Dogan S, Balli U, Avci B, Durmușlar MC. The effect of initial periodontal treatment on plasma, gingival crevicular fluid and salivary levels of 8-hydroxy-deoxyguanosine in obesity. Arch Oral Biol. 2016; 62:80-5.

35. Suvan J, Petrie A, Moles DR, Nibali L, Patel K, Darbar U, et al. Body mass index as a predictive factor of periodontal therapy outcomes. J Dent Res. 2014;93:49-54.

36. Altay U, Gürgan CA, Ağbaht K. Changes in inflammatory and metabolic parameters after periodontal treatment in patients with and without obesity. J Periodontol. 2013;84:13-23.

37. Al-Zahrani MS, Alghamdi HS. Effect of periodontal treatment on serum C-reactive protein level in obese and normal-weight women affected with chronic periodontitis. Saudi Med J. 2012;33:309-14.

38. Zuza EP, Barroso EM, Carrareto AL, Pires JR, Carlos IZ, Theodoro LH, et al. The role of obesity as a modifying factor in patients undergoing non-surgical periodontal therapy. J Periodontol. 2011;82:676-82

39. Aljehani Y. Risk factors of periodontal disease: review of the literature. Int J Dent. 2014;2014:182513.

40. Khosravi R, Ka K, Huang T, Khalili S, Hong B, Nicolau B, et al. Tumor necrosis factor- $\alpha$ and interleukin-6: potential interorgan inflammatory mediators contributing to destructive periodontal disease in obesity or metabolic syndrome. Mediators Inflamm. 2013;2013:728987.

\section{Conflicts of Interest}

The authors declare that they have no conflicts of interest in relation to this study.

M.M-H is recipient of a predoctoral fellowship from the Regional Ministry Education of Valencian Community (ACIF/2015/226). 